\title{
Development of Electronic Learning Methods Using the Project-Based Learning Method
}

\author{
Darwison $^{1}$, Primas Emeraldi ${ }^{2}$, Rudy Fernandez ${ }^{3}$ \\ \{darwison@eng.unand.ac.id ${ }^{1}$ \} \\ 1,2,3 Department of Electrical Engineering, Faculty of Engineering, Andalas University, Padang, \\ Indonesia
}

\begin{abstract}
With the rapid development of science at this time and the criteria for recruitment of workers who need soft skills, the Teaching and Learning Process (PBM) applying the Teacher Center Learning (TCL) method is no longer appropriate. The application of the Student Center Learning (SCL), which emphasizes on the ProjectBased Learning ( $\mathrm{PjBL}$ ) method is needed. The assessment is not only on hard skills (such as Tasks, Examinations, Exams, Exercises, Quizzes, group presentations, and Major Tasks) but also on soft skills. Using the SCL-PjBL method in PBM will be able to increase the maximum absorption of knowledge to students. Besides, the students must be prepared in terms of lecture material, which will be presented by more challenged lectures to be better prepared because the SCL-PjBL method makes more lecturers as facilitators. The results of the assessment of Electronics courses with the application of the SCL-PjBL method for 131 students in the 2018/2019 school year obtained an average score of soft skills of $72 \%$ from a $40 \%$ rating or 28.8 on a 100 scale.
\end{abstract}

Keywords: Student-Centered Learning, Teacher-Centered Learning, Project-Based Learning, soft skills, and Assessment.

\section{Introduction}

The position of the Electronics course in the curriculum structure of the Electrical Engineering Department is the compulsory (Core) subject in semester II which requires the compulsory subject namely the Electricity Circuit in semester II. The competencies are: 1) Students are able to explain Electronic components and examples of applications that are used in the community. 2) Students are able to explain and design a series of simple electronic applications using basic electronic components such as transistors, op-amps, relays, SCRs, sensors and others. Simple electronic applications can be in the form of water tank controls, room security, safes, line follower robots and others. With these competencies, this course can support the making of Final Projects related to an application in the form of a hardware device.

The learning method applied so far still uses the TCL method [1]. At the beginning of the lecture, the lecturer explains the material to be obtained during the lecture which is outlined through the Semester Learning and Program Plan (RPKPS). At each meeting, the lecturer 
explained the lecture material, was given the opportunity to ask questions, tried to have training, quizzes and the end of the lecture were given assignments.

Assessment carried out in measuring student learning outcomes applied so far is through training, quizzes, assignments, Semester Final Exams (UTS) and Final Semester Exams (UAS). Tasks are collected one day before the next meeting in the form of softcopy to the Digital Electronics laboratory. Tasks will be discussed at the next meeting and even then if anyone wants to ask about the assignment. UTS and UAS are open books and the results are in the form of simulations.

The percentage distribution of grades at the end of the semester for the last two years is the 2016/2017 school year and the 2017/2018 school year is like Figure 1.

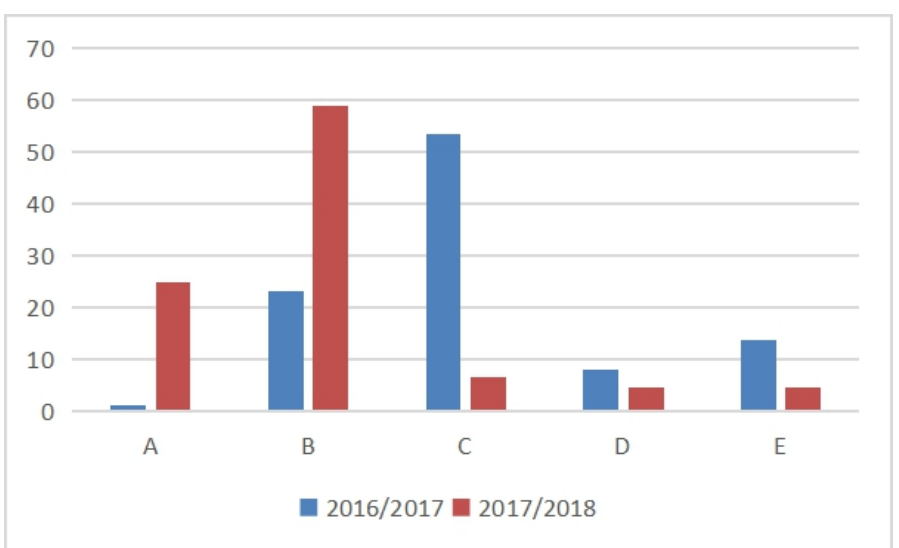

Figure 1. Percentage of distribution of grades in the last two years

In FY 2016/2017 the electronic value graph tends to be a normal distribution with a value of $\mathrm{C}$ of $54 \%$ and FY 2017/2018 an electronic value chart tends to be a normal distribution leaning to the left with a value of B of 59\%. There is an increase in the electronic value which is quite high in the 2017/2018 FY due to the implementation of remedial 2 times according to the recommendations of WR1 Unand.

Based on the above background, the problems that arise in achieving student learning outcomes in applying the TCL method so far are:

1. Lack of active students in lectures and group discussions such as asking questions, answering questions and giving suggestions on group presentations.

2. Tasks collected mostly besides copy \& paste are also often not asked at the next meeting.

To overcome the problem of PBM, SCL is applied which emphasizes the Project Based Learning (SCL-PjBL) method which aims to make students:

a. more actively asking questions, answering questions and expressing opinions or suggestions during lectures, group discussions, quiz presentations, exercises, assignments and final project applications.

b. passionate about making assignments in person or in groups.

c. create soft skills competence both intrapersonal skills (independence, critical and analytical thinking) and interpersonal skills (work in teams and oral communication), and basic values of students (integrity, discipline, hard work, courtesy / ethics / values, and trust self). 
The SCL-PjBL method is expected to motivate curiosity and student learning enthusiasm towards the development of student character (life-long learning) to achieve an expected hard skill competency without ignoring soft skills competencies [2]-[4]. In soft skills competencies, among others, can build the basic values of students during the teaching and learning process such as integrity, discipline, hard work, courtesy / ethics / have values, and confidence which will all shape the character of students [5], [6].

\section{Methods}

\section{Strategy for Achieving Outputs Learning Plans}

Based on the above objectives, it is necessary to plan Electronics course learning as an effort to improve the previous learning methods to be more effective and efficient in achieving graduate competencies. Semester Learning Plans in the previous period, or still known as RPKPS (Semester Learning and Lecture Activities) can be accessed in dropbox (a program that can be used for file sharing over the network). The design of the new RPKPS as a revision from the previous RPPKS uses the application of SCL with the PjBL method according to the learning outcomes mentioned above, including evaluating to student class participants.

\section{Development of Learning Methods}

$\mathrm{PjBL}$ is one of systematic learning that invites students to learn knowledge and skills through a structured process of inquiry about questions and products and tasks that are complex, authentic and carefully designed. The application of the PjBL in Electronics courses will increasingly provide knowledge, insight, skills and understanding to class participants how to design a simple electronic application can be in the form of water tank control, room security, safes, line follower robots and others. Starting from the planning stage, organizing, actuating and controlling, as well as the stages of analysis, design, implementation, and testing so that the elements that need to be included in the application of the PjBL in the Electronics course are:

1. Increased skills knowledge about Electronics,

2. Exploring knowledge and insights in managing Electronic applications,

3. Discussion of application results set by students with the guidance of lecturers,

4. Increased skills in problem solving, teamwork. Great communication and creativity skills in making applications,

5. The ability of innovation in making applications,

6. There is a great motivation that arouses student interest in creating an electronic application with adequate management.

For SCL models [7], [8] with the PjBL method applied to support the implementation of soft skills [6] in learning are:

1. Small Group Discussion students form their own groups where 1 group consists of 2 to 3 people. Select the discussion material (Electronic circuit) and present the results of the discussion in class. While the task of the lecturer is to make a discussion material design, become a moderator and at the same time review each end of the group discussion of students who appear. 
2. Simulation is a student simulating the discussion material chosen in the form of series and programs and the lecturer discusses student performance and evaluates each student's soft skills.

3. Collaborative Learning is a student in his group looking for and simulating an application of innovation in the form of water tank control, room security, safes, line follower robots and others while the lecturer as a facilitator and motivator in producing simulation innovations.

\section{Development of student assessment}

The development of a scoring system in the Electronics course is by assessing the teaching and learning process in the classroom such as the participation and activity of question and answer, practice, quizzes, assignments, assignments and assignments. Simple electronic applications and soft skills competency assessment both intrapersonal skills and interpersonal skills and values basic student while evaluating results through midterms (UTS), Semester Final Exams (UAS) and Tasks Simple electronic applications in the form of making application tools in the form of simulations using the Multisim or Proteus program. The plan for developing this grading system as in table 1 below;

Table 1. Assessment System Development Plan

\begin{tabular}{|c|c|c|}
\hline No. & Assessment Components & Weight (\%) \\
\hline \multicolumn{3}{|c|}{ 1. Rating results } \\
\hline a. & Midterm exam (UTS) & 20 \\
\hline b. & Final exams (UAS) & 20 \\
\hline c. & Simple electronics application tasks (simulation) & 15 \\
\hline \multicolumn{3}{|c|}{ 2. Assessment process } \\
\hline \multicolumn{3}{|c|}{ a. Participation and active question and answer in terms of: } \\
\hline & - Exercise & 5 \\
\hline & - Quiz & 5 \\
\hline & - Weekly assignments & 5 \\
\hline & - Presentation of Assignments (according to lecture material) & 5 \\
\hline & $\begin{array}{l}\text { - Presentation of Simple Electronic Application Tasks (simulation)) (can be } \\
\text { used as an improvement in UTS or UAS grades) }\end{array}$ & 10 \\
\hline \multicolumn{3}{|c|}{ b. softskill competencies include: } \\
\hline & - intrapersonal skills (independence, critical and analytical thinking), & 5 \\
\hline & - interpersonal skills (teamwork and verbal communication) and & 5 \\
\hline & $\begin{array}{l}\text { - basic values of students (integrity, discipline, hard work, polite / ethical / } \\
\text { have values, and have confidence) }\end{array}$ & 5 \\
\hline Total & & 100 \\
\hline
\end{tabular}

The assessments used included three types, namely teacher-based assessment, peer assessment, and self-assessment [9], [10]. The strategies adopted for assessment include: exercises, quizzes, assignments, presentations, written examinations (UTS \& UAS) and observations. Exercises, quizzes and assignments are used to assess knowledge and understanding. Presentations, in addition to the assessment of knowledge and understanding, are also used to assess communication skills. And written examinations are essentially crosschecks for self-assessment and reviewing individual contributions to the team. Meanwhile, the assessment of the dynamics of the team / individual is done through observation. The value of 
this observation is very large if students are often active such as training, quizzes \& presentations in individuals and groups.

\section{Classroom Action Research Parameters (CAR)}

Classroom Action Research is practical research intended to improve teaching and learning in the classroom. This improvement effort is carried out by carrying out actions to look for answers to inactivity and tie students' enthusiasm from the daily tasks in the classroom. So that PTK will produce learning outcomes as mentioned above, the broader distribution of values includes results and processes and concludes the results of the Development of Electronic Learning Methods Using Project Based Learning Methods

\section{Results and Discussion}

The photos of the learning activities using the SCL method which emphasize the PjBL as shown in Figure 2. Figure 2a and Figure $2 b$ illustrate the activity of the students offered by the lecturers in answering questions in the training activities and quizzes presented per group. And Figure 2c and Figure 2d illustrate the activity of students offered by lecturers in discussions during group presentations for group assignments and large tasks (tool application simulation). Figure 2e illustrates active students in answering questions through a presentation of a simulation circuit. And picture $2 \mathrm{f}$ when students are examining both UTS and UAS.

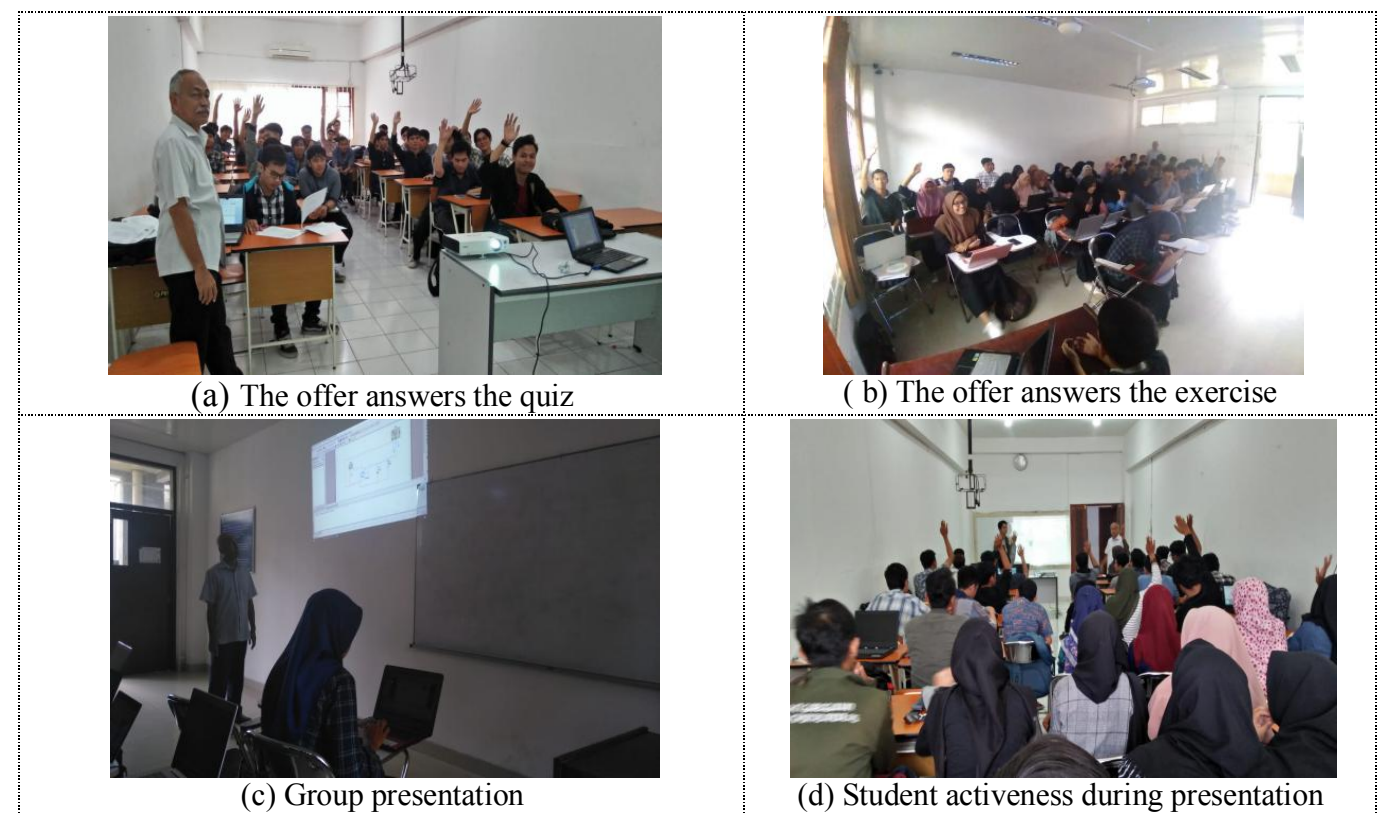




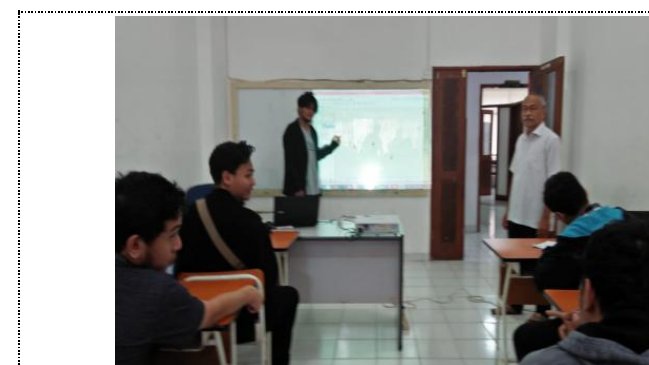

(e) Student presentation in answering questions

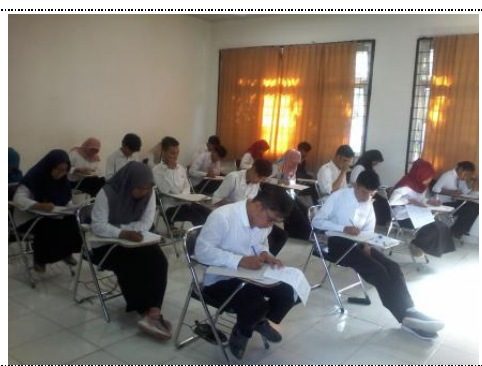

(f) During the UTS exam

Figure 2. Student activeness in PBM activities

The quantitative data about the final value of each soft skills' attribute and the final value of the combination of soft skills and soft skills are as in table 2 .

Table 2. Quantitative values of soft skills in Electronics

\begin{tabular}{|c|c|c|c|c|c|c|}
\hline \multirow[b]{2}{*}{ No. } & \multirow[b]{2}{*}{ Competence } & \multicolumn{5}{|c|}{ Activity (\%) } \\
\hline & & 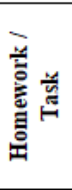 & 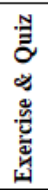 & 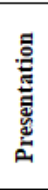 & 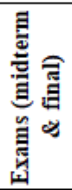 & 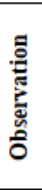 \\
\hline \multirow[t]{5}{*}{1} & \multicolumn{6}{|l|}{ Intrapersonal skill } \\
\hline & 1.1 Mandiri & 95 & 56 & 66 & 96 & \\
\hline & 1.2. Critical thinking & & 46 & 56 & & \\
\hline & 1.3. Analytical & & 46 & 66 & 70 & \\
\hline & Average $=62,8 \%$ & 95 & 49 & 63 & 83 & \\
\hline \multirow[t]{9}{*}{2} & \multicolumn{6}{|l|}{ Interpersonal skill } \\
\hline & \multicolumn{6}{|l|}{\begin{tabular}{l|l} 
Teamwork \\
\end{tabular}} \\
\hline & 2.1 Leadership & & 56 & 56 & & 56 \\
\hline & 2.2 Communication Norms & & 56 & 56 & & 56 \\
\hline & 2.3 Effectiveness & & 70 & 70 & & 70 \\
\hline & \multicolumn{6}{|l|}{ Communication skills } \\
\hline & 2.4 Oral communication & & 56 & 56 & & \\
\hline & 2.5 Written communication & & 80 & & 80 & \\
\hline & Average $=55,1 \%$ & & 64 & 60 & 80 & 61 \\
\hline \multirow[t]{7}{*}{3} & \multicolumn{6}{|c|}{$\begin{array}{l}\text { Basic values of students, discipline, hard work, polite / ethical / have values, } \\
\text { and have confidence }\end{array}$} \\
\hline & 3.1 Integrity & 70 & & & 90 & 90 \\
\hline & 3.2 Discipline & 90 & & & & 90 \\
\hline & 3.3 hard work & & 66 & & 70 & 80 \\
\hline & 3.4 Polite / ethical / have values & & & & & 90 \\
\hline & 3.5 Confidence & & & & & 70 \\
\hline & Average $=71,25 \%$ & 80 & 66 & & 80 & 84 \\
\hline
\end{tabular}

From table 2, the average for the three soft skills attributes is:

The total soft skills average $=(72.5 \%+66 \%+77.5) / 3=72 \%$

Thus, the value of soft skills is $72 \%$ of the $40 \%$ assessment, which is 28.8 on a scale of 100. This 28.8 score is the average soft skills score for 131 students in 3 classes who took 
Electronics courses in the even semester of the Academic Year ( TA) 2018/2019. It can be concluded that the average score of students' soft skills taking Electronics courses is quite sufficient for students who are active in class activities. It is still considered quite the value of this soft skill because the SCL-PjBL system is still only being implemented this year and the application of this method for the following year will increase along with the students being familiar with the system.

The distribution of the final value of Electronics courses in the even semester 2018/2019 is as shown in Figure 3. This electronic value graph is in the form of a normal distribution with a maximum peak of $\mathrm{B}+$. Class $\mathrm{B}$ and class $\mathrm{C}$ have a normal distribution that is leaning to the left or worth better than class A. In general the assessment of Electronics courses is better than the previous 2 years ie there is no value $<\mathrm{B}$ - except students who do not make assignments and absent $<75 \%$. So it can be concluded that with the implementation of SCL$\mathrm{PjBL}$ which emphasizes the assessment of soft skills by $40 \%$, it will have an impact on rising average values and students becoming more active. Even so, it should be noted that this better value distribution in addition to the contribution of soft skills is also given the opportunity for students to take remedial values. B. The percentage of students participating in remedials is an average of $87.5 \%$ of the three classes in Electronics.

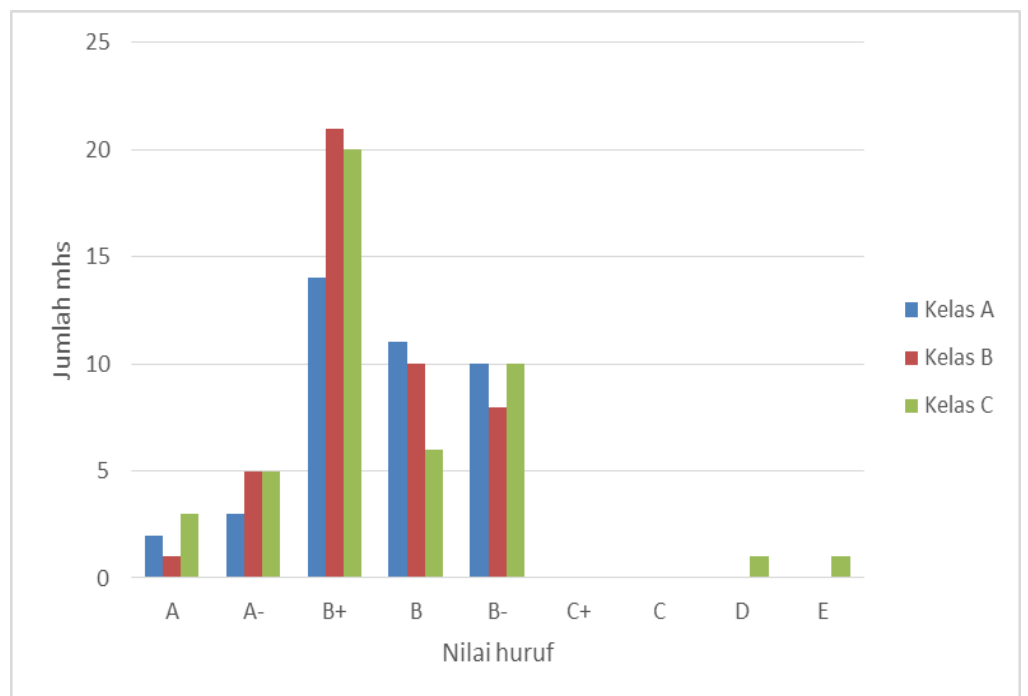

Figure 3. Final Value of Electronics courses in even semester 2018/2019

To measure the success rate of SCL-PjBL, questionnaires were distributed to students whose results were like table 3 . From the questionnaire it can be concluded that the success rate of the SCL method by emphasizing on $\mathrm{PjBL}$ is equal to $80.36 \%$ of 20 student questionnaires taken randomly. 
Table 3. Student questionnaire for Electronics courses

\begin{tabular}{|c|c|c|c|c|}
\hline & \multicolumn{4}{|c|}{ Kuisioner (Instrumen evaluasi implementasi soft skills dalam SCL) mahasiswa } \\
\hline & \multirow{2}{*}{ Question } & \multicolumn{3}{|c|}{ Answer } \\
\hline & & yes & no & $\%$ yes \\
\hline \multirow{3}{*}{ A } & \multicolumn{4}{|l|}{ Soft skills perception } \\
\hline & \begin{tabular}{|l|l|}
1 & Mastery of science \\
\end{tabular} & 17 & 3 & 85.00 \\
\hline & \begin{tabular}{|l|l|}
2 & Application of soft skills \\
\end{tabular} & 15 & 5 & 75.00 \\
\hline \multirow{5}{*}{ B } & \multicolumn{4}{|l|}{ Soft skills planning } \\
\hline & \begin{tabular}{|l|l|}
1 & RPS has soft skill attributes \\
\end{tabular} & 14 & 6 & 70.00 \\
\hline & \begin{tabular}{l|l|}
2 & RPS has the weight of soft skills assessment \\
\end{tabular} & 16 & 4 & 80.00 \\
\hline & \begin{tabular}{l|l}
3 & Soft skills assessment score \\
\end{tabular} & 17 & 3 & 85.00 \\
\hline & \begin{tabular}{|l|l|}
4 & RPS is given to students \\
\end{tabular} & 17 & 3 & 85.00 \\
\hline \multirow{5}{*}{$\mathrm{C}$} & \multicolumn{4}{|l|}{ Soft skills implementation } \\
\hline & \begin{tabular}{|r|l|}
1 & Lecturer explains the attributes of soft skills \\
\end{tabular} & 16 & 4 & 80.00 \\
\hline & \begin{tabular}{l|l}
2 & $\mathrm{SCL}$ models support the improvement of soft skills \\
\end{tabular} & 17 & 3 & 85.00 \\
\hline & \begin{tabular}{l|l}
3 & Lecturers motivate to achieve soft skills \\
\end{tabular} & 14 & 6 & 70.00 \\
\hline & \begin{tabular}{|l|l|}
4 & Lecturers give feedback on soft skills achievements \\
\end{tabular} & 17 & 3 & 85.00 \\
\hline \multirow{3}{*}{$\mathrm{D}$} & \multicolumn{4}{|l|}{ Soft skills assessment } \\
\hline & \begin{tabular}{|l|l|}
1 & Soft skills attributes are assessed during lectures \\
\end{tabular} & 15 & 5 & 75.00 \\
\hline & \begin{tabular}{l|l|}
2 & lecturers give feedback on the achievement of soft skills \\
\end{tabular} & 15 & 5 & 75.00 \\
\hline \multirow{3}{*}{$\mathrm{E}$} & \multicolumn{4}{|l|}{ Impact } \\
\hline & \begin{tabular}{|l|l|}
1 & Soft skills value helps the final grade \\
\end{tabular} & 17 & 3 & 85.00 \\
\hline & \begin{tabular}{l|l}
2 & Students are more confident than applying soft skills \\
\end{tabular} & 18 & 2 & 90.00 \\
\hline & Note: 20 questionnaires & \multicolumn{2}{|c|}{ Total } & 80.36 \\
\hline
\end{tabular}

\section{Conclusion}

By applying the method of teaching Electronics by SCL-PjBL with 3 learning objectives so that conclusions can be drawn from this study are:

1. The average value of Soft skills in Electronics is $72 \%$ or 28.8 on a 100 scale.

2. The graphs for evaluating Electronics courses 2018/2019 are normally distributed with those that get $\mathrm{B}+$ values averaging $42 \%$, which is almost the same as the previous TA but almost nothing is worth $<\mathrm{B}$.

3. The success rate of the SCL method by emphasizing the PjBL is equal to $80.36 \%$ of the 20 student questionnaires taken randomly.

4. Understanding of hard skills is better based on soft skills value taking activities starting from exercises, quizzes, assignments, and group presentations.

\section{Recommendation}

To improve understanding of hard skills in terms of training, quizzes, assignments, group presentations through personal blogs, hard skills assessment methods need to be made online and realtime using ilearn - Unand. 


\section{Acknowledgment}

Authors thank LembagaPengembanganPendidikan dan PenjaminanMutu (LP3M) UniversitasAndalas, Padang, Indonesia that funded this research with contract no.: 08/UN.16.18/PT.01.03/2019.

\section{References}

[1] Blumberg Phyllis, 2014, Learner-Centered Teaching, University of the Sciences, Philadelphia.

[2] Angele Attard, Emma Di Ioio, Koen Geven, and Robert Santa, 2010, Student Centered Learning An Insight Into Theory And Practice, Bucharest

[3] Angele Attard, Emma Di Iorio, Koen Geven, and Robert Santa, 2010, Student-Centred LearningToolkit for students, staff and higher education institutions, Laserline, Berlin

[4] Attard, Angele; Iorio, Emma Di; Geven, Koen; Santa, Robert (2014). Student-Centered Learning SCL Toolkit, Brussels: European Students' Union

[5] Department of labor, 2010, Teaching Soft Skills Through Workplace Simulations in Classroom Settings, ODEP, U.S.

[6] DwinCancino, Soft skills methods of teaching and assessment, Associate Professor at King Faisal University, Uploaded on Jan 20, 2013

[7] Geraldine O'Neill and Tim McMahon, 2005, Student-centred learning: What does it mean for students and lecturers?,Dublin:AISHE

[8] Koen Geven and Robert Santa, 2010, Student Centered Learning: Survey Analysis Time for Student Centred Learning, Bucharest

[9] Kenji Takahashi, 2014, Assessment For, Of and As Learning, SchoolWorld

[10] Mohamed NaimDaipi, penilaianuntukpembelajaran, Master Teacher at Curriculum Planning and Development Division, Ministry of Education, Uploaded on Sep 26, 2009 